http://nv.nltu.edu.ua

https://doi.org/10.15421/40280406

Article received 04.04.2018 p.

Article accepted 26.04.2018 p.

ISSN 2519-2477 (online)

УдК 339.9

$@ \bowtie$ Correspondence author

V. M. Melnyk

Millervm@ukr.net

Т. Б. Данилович, А. С. Гавриляк, В. М. Мельник

Національний університет "Львівська політехніка", м. Львів, Україна

\title{
ФОРМУВАННЯ СТУДЕНТСЬКИХ МАЙДАНЧИКІВ КОМЕРЦІАЛІЗАЦІЇ БІЗНЕС-ІДЕЙ ТА ФОРМАЛІЗАЦІЇ СОЦІАЛЬНИХ ІНІЦІАТИВ
}

Висвітлено проблеми молодіжного підприємництва, показано роль та особливості функціонування вітчизняних і міжнародних структур університетського середовища, які працюють у сфері надання консультацій у створенні і веденні власного бізнесу. Показано, що попри безсумнівну ефективність цих структур у підготовці студентів до роботи у сучасних міжнародних та вітчизняних компаніях та наданні глибоких теоретичних знань з формування бізнесу, є неможливим, у рамках таких шкіл, прищеплення студентам вузькоспеціалізованих практичних навичок для ведення чітко визначеного бізнесу. Висвітлено проблеми реалізації соціальних студентських ініціатив та залучення міжнародних донорських організацій до їх фінансування. Обгрунтовано доцільність створення студентських майданчиків, як складової частини молодіжного і університетського підприємництва, на якому будуть створені умови для: студентів, щодо реалізації власних соціальних і бізнес-ідей; підприємців, які хочуть розвивати бізнес; освітян, науковців, фахівців, що прагнуть "інвестувати" власні знання, навики і досвід у реалізацію студентських ідей; університетів, що отримуватимуть замовлення від бізнесу на підготовку фахівців з чітко визначеними компетентностями. Запропоновано модель поетапного створення студентського майданчика 3 побудовою інфраструктури на базі вишів, профтехучилищ, коледжів, громадських організацій та технопарків і системою комунікаційних зв'язків між студентом, викладачем, підприємцем, освітнім закладом і місцевою владою, які в процесі комерціалізації бізнес-ідеї або формалізації соціальної ініціативи переростатимуть у партнерські або ділові.

Ключові слова: молодіжне підприємництво; комунікаційні зв'язки; соціальне підприємство; університетське середовище; компетентності.

Вступ. Кризові ситуації у вітчизняній економіці спонукають молодих та ініціативних студентів до пошуку нових форм самореалізації, які дадуть їм змогу стати фінансово незалежними та власними силами будувати своє майбутнє. Однією із таких форм самореалізації та самоутвердження молодої людини є втілення в життя власних ідей. Під час навчання, отримання знань і навичок, аналізу соціальних та економічних проблем, у студентів виникають ідеї щодо шляхів їх вирішення. Однак, не маючи досвіду в реалізації своїх ідей, не знаючи, як викласти їх "на папері", не володіючи спеціалізованими знаннями у певній сфері, а зрештою нерішучість і невміння ці ідеї відстоювати, призводять до того, що багато неординарних та інноваційних ідей залишаються не реалізованими або переводяться в розряд безперспективних. Так, для прикладу, можна взяти ідею створення такої великої соціальної мережі як Facebook, яка, на початку, здавалась для багатьох не цікавою і такою, що в майбутньому не принесе користі ні для суспільства, ні для розробника. Однак, завдяки тому, що власник ідеї зумів переконати та зацікавити студентів, створивши команду однодумців, яка і реалізувала іiі, людство отримало один із найефективніших комунікаційних інструментів сьогодення.

Аналіз останніх досліджень і публікацій. Деякі питання теорії та практики молодіжного підприємництва в університетському середовищі та середовищі соціального підприємництва досліджували вітчизняні науковці: Л. В. Дейнеко (2017), І. Ю. Думанська (2013), I. С. Каленюк (2016), А. Ф. Павленко (2014), О. О. Романовський $(2012,2015)$, Н. І. Чухрай (2011) та ін.

Проте, незважаючи на численні публікації, які присвячені молодіжному підприємництву в різних сферах діяльності, невирішеним залишається питання побудови ефективних комунікаційних та ділових зв'язків між студентом, викладачем, підприємцем, університетом та місцевою владою щодо реалізації студентом власних соціальних ініціатив та бізнес-ідей.

На сьогодні у світі та в Україні є багато структур, які працюють у сфері надання консультацій у створенні

\section{Інформація про авторів:}

Данилович Тарас Богданович, канд. екон. наук, доцент, кафедра економіки підприємства і інвестицій. Email: Dant33@rambler.ru

Гавриляк Анатолій Степанович, канд. техн. наук, доцент, кафедра економіки підприємства і інвестицій. Email: Ganatol71@ukr.net

Мельник Володимир Мирославович, канд. техн. наук, доцент, кафедра економіки підприємства і інвестицій. Email: Millervm@ukr.net

Цитування за ДСтУ: Данилович Т. Б., Гавриляк А. С., Мельник В. М. Формування студентських майданчиків комерціалізації бізнес-ідей та формалізації соціальних ініціатив. Науковий вісник НлтУ України. Серія Економічна. 2018, т. 28, № 4. С. 36-40

Citation APA: Danylovych, T. B., Havryliak, A. S., \& Melnyk, V. M. (2018). Forming Student Platforms to Commercialize Business Ideas and to Formalize Social Initiatives. Scientific Bulletin of UNFU, 28(4), 36-40. https://doi.org/10.15421/40280406 
і веденні власного бізнесу. 3 них можна виділити такі вітчизняні: Tech StartUp School, Youth \& Business, Бізнес-школа при Київо-Могилянській академії, Львівська бізнес-школа (LvBS), які орієнтовані на студентську молодь. Серед бізнес-шкіл світу найкращими, за даними Financial Times, вважають Insead (Франція), Гарвардську бізнес-школу (США), Лондонську бізнес-школу (Британія/ОАЕ), Уортонську бізнес-школу (США), Стенфордську бізнес-школу (США) та ін. Світові лідери серед бізнес-шкіл зазвичай проводять навчання за програмою МВА й орієнтовані на підготовку і працевлаштування студентів у великих міжнародних компаніях, а фахівців для малого та середнього бізнесу не готують. Українські бізнес-школи дають більше теоретичних знань, а саме: як подати та презентувати ідею; як сформувати команду; як налагодити комунікації 3 потенційними інвесторами та переконати їх вкласти кошти в запропоновану ідею; як створити бізнес. Однак вузькоспеціалізованих практичних навичок для ведення чітко визначеного студентом бізнесу вони не надають, оскільки це неможливо зробити в рамках таких шкіл. Така ситуація призводить до того, що молода людина, яка отримала теоретичні та загальні навички і хоче створити власну справу, під час реалізації бізнес-ідеї неспроможна її комерціалізувати, оскільки не має практичних навичок і не знає особливостей ведення бізнесу у цій сфері. При цьому, навчання в таких школах, зазвичай, орієнтоване на управління бізнесом і частково на його організацію, а щодо отримання практичних навичок, які передбачені в процесі тренінгу, то вони є ситуаційні i, на нашу думку, деклараційні. Наступним недоліком таких шкіл $\epsilon$ те, що вони запрошують студентів до співпраці, а не працюють безпосередньо в студентському середовищі, і як наслідок, відсутній зворотний зв'язок студент $\rightarrow$ бізнес-школа.

Особливу увагу заслуговують студентські соціальні ініціативи, які повинні реалізовуватись через соціальні проекти. У напрямку реалізації соціальних ініціатив працюють міжнародні фонди та донори, зокрема, такі, як, Європейська молодіжна фундація, Фонд ERSTE, Фонд "Монсанто", Агентство США 3 міжнародного розвитку (USAID) та ін., які через гранти та різноманітні програми фінансують соціальні проекти. На грантову підтримку соціальних проектів виділяє кошти і місцева влада. Проте однією з особливостей цих грантів і програм $\epsilon$ те, що виконавцями проекту, зазвичай, повинні бути неприбуткові громадські організації або об'єднання громад, а це приводить до необхідності пошуку студентом таких структур для реалізації власних соціальних ініціатив. Треба зазначити, що такі структури не завжди спроможні, з різних причин, оцінити та реалізувати запропоновані соціальні ініціативи.

Наступна проблема, з якою стикаються студенти, це формалізація соціальної ідеї, оскільки вони не мають практичних навичок у написанні проектів, не знають специфіки оформлення соціальних проектів за формами, які надають міжнародні донорські організації та фонди. Студенти, також, не мають чіткої інформації, як працює соціальне підприємство, їм незрозумілі механізми його створення і функціонування, які податкові преференції воно отримує та як ними користуватись.

Метою дослідження $є$ обгрунтування доцільності створення студентських майданчиків комерціалізації бізнес-ідей та формалізації соціальних ініціатив як складової частини молодіжного та університетського підприємництва.

Основні результати дослідження. Дослідження, проведене в студентському середовищі щодо ефективності реалізації власних ідей, спрямоване на розкриття творчого та бізнесового потенціалу молоді, дало змогу сформувати низку проблем, з якими стикаються студенти, а саме:

- застарілий підхід "спочатку завершити навчання, а потім займатися підприємницькою діяльністю";

- неспроможність формалізувати ідею;

- відсутність студентських комунікаційних майданчиків, де власник ідеї може іï презентувати і сформувати команду однодумців, яка буде її реалізовувати;

- порівняно висока оплата бізнес-тренінгів (курсів), які проводять бізнес-школи, при цьому надаючи слухачам, зазвичай, теоретичні знання і загальні практичні навики;

- складність з отриманням спеціалізованих знань щодо реалізації ідеї;

• втрати унікальності ідеї через консерватизм більшості викладачів;

- невміння використовувати доступні інструменти фінансування етапів реалізації ідеї;

- брак навичок та інформації про те, як і де можна "продати" власну ідею;

• відсутність інформації про інноваційно-інвестиційні структури, які покликані допомагати впроваджувати ідеї тощо.

Для вирішення проблем, які були виявлені в процесі дослідження, пропонуємо створення окремого студентського майданчика для формалізації соціальних ініціатив та комерціалізації бізнес-ідей (надалі Майданчик), на якому будуть створені умови для:

- студентів, щодо реалізації власних соціальних і бізнес-ідей;

- підприємців, які прагнуть розвивати бізнес, залучати креативних молодих фахівців у власний бізнес і проводити їх практичну підготовку;

- освітян, науковців, фахівців, експертів, консультантів, практиків, "інвестувати" власні знання, навики, досвід у реалізацію студентських ідей, створюючи спільні соціальні та комерційні підприємства;

- університетів, які отримуватимуть замовлення від бізнесу на підготовку фахівців 3 чітко визначеними компетентностями, необхідним рівнем знань та практичних навичок, і як наслідок, можливість для трансформації навчальних університетів в підприємницькі університети.

Важливу роль у забезпеченні комфортних умов для створення та ведення молодіжного бізнесу на Майданчику повинні відігравати місцеві органи влади, зокрема, в організації сприятливої фінансово-кредитної політики через програми підтримки молодіжного підприємництва.

Одним із основних завдань Майданчика є побудова комунікаційних зв'язків між студентом $\rightarrow$ викладачем $\rightarrow$ бізнесменом $\rightarrow$ бізнес-тренером, які в процесі комерціалізації бізнес-ідеї або формалізації соціальної ініціативи переростають у партнерські або ділові. Особливістю Майданчика $є$ те, що ініціаторами його створення виступатимуть студенти та викладачі вищих навчальних закладів (ВН3), профтехучилищ та коледжів регіону за підтримки місцевих органів влади.

Пропонуємо таку модель поетапного створення студентського майданчика формалізації соціальних ідей та комерціалізації бізнес-ідей (рисунок). 


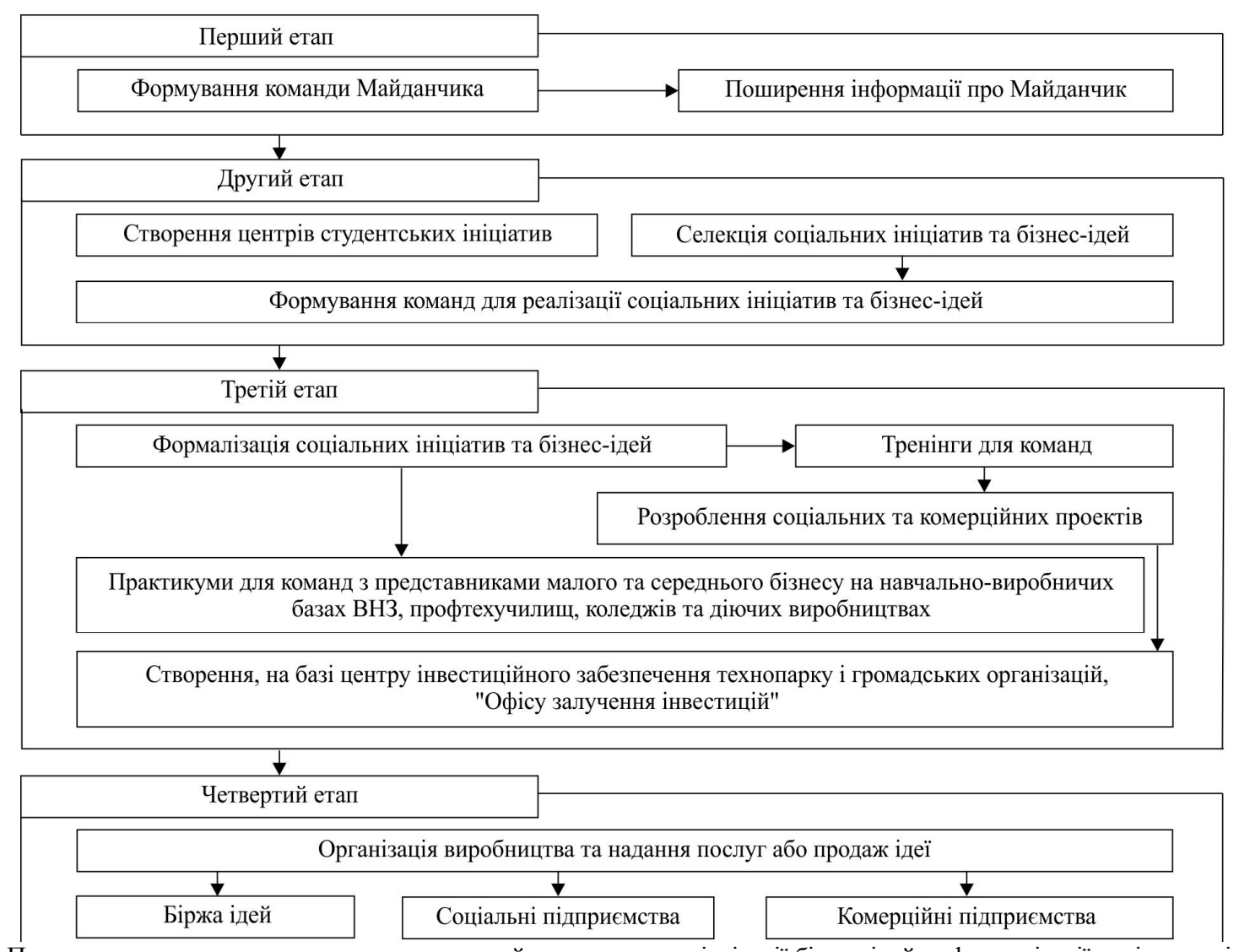

Рисунок. Поетапна модель створення студентського майданчика комерціалізації бізнес-ідей та формалізації соціальних ініціатив

Розглянемо етапи побудови Майданчика, які наведено на рисунок, і дамо їм коротку характеристику.

Перший етап побудови Майданчика - це формування команди студентів і викладачів ВНЗ, профтехучилищ та коледжів регіону для розповсюдження інформації, з якою метою створюють Майданчик, які його цілі та завдання і яким чином студенти можуть отримати допомогу в реалізації власних соціальних та комерційних ідей. Цей етап передбачає: створення веб-сайту; поширення інформації в соціальних мережах; розповсюдження інформаційних презентацій по ВНЗ, профтехучилищах та коледжах регіону; проведення флешмобів; представлення презентацій у громадських організаціях та в органах місцевої влади.

Другий етап передбачає пошук та відбір креативних соціальних ініціатив та бізнес-ідей, формування команд ініціативних студентів, що вже здобули певні теоретичні знання та початкові практичні навики з різних спеціальностей, які будуть групуватися за інтересами та напрямками ідей. Тобто під кожну окрему соціальну або комерційну ідею створюватимуть команду, яка планує iii реалізувати. Реалізація цього етапу передбачає створення центрів студентських ініціатив на базі ВНЗ, профтехучилищ, коледжів, громадських організацій та технопарків, на яких студенти можуть поділитись власними ідеями та, за допомогою викладачів, визначити недоліки, переваги та доцільність щодо їх впровадження. Кінцевим результатом цього етапу є сформовані команди, які об'єднуються для реалізації конкретної соціальної або бізнесової ідеї.

На третьому етапі сформовані команди разом з викладачами, бізнес-тренерами, представниками бізнесу i громадських організацій, фахівцями спеціалізованих підрозділів технопарку формалізують ідеї та представляють бізнес-проекти, соціальні проекти на інформа- ційних платформах ВНЗ, громадських організацій, технопарків і місцевих органів влади. Цей етап передбачає проведення: тренінгів із формалізації ідей, їх комерціалізації та загальних навиків з ведення бізнесу, які проходять в діючих бізнес-школах, ВН3, громадських організаціях і технопарках; практичних занять представниками малого та середнього бізнесу на діючих підприємствах та навчально-виробничих базах ВНЗ, профтехучилищ, коледжів і виробничих підприємствах технопарків. Для фінансування соціальних та комерційних студентських проектів створюють "Офіс залучення інвестицій", на базі Центру інвестиційного забезпечення технопарку і громадських організацій, для залучення фінансових ресурсів у проекти Майданчика через донорські організації, фонди та програми, як вітчизняні, так і міжнародні.

На цьому етапі виникає потреба у вузькоспеціалізованих знаннях і навичках для реалізації проектів, що диктує потреба у зміні навчальних планів і програм підготовки фахівців ВНЗ, профтехучилищ та коледжів.

Четвертим етапом побудови Майданчика комерціалізації бізнес-ідей та формалізації соціальних ініціатив $\epsilon$ організація виробництва та надання послуг або продаж ідеї. Цей етап передбачає також створення Біржі ідей, на якій студенти самостійно зможуть виставити власні соціальні та комерційні проекти, які не отримали фінансової підтримки на третьому етапі, і здійснити пошук донорів або інвесторів для їх фінансування.

Кінцевий етап формалізації соціальних ініціатив та комерціалізації бізнес-ідей передбачає, що соціальні проекти повинні поступово інтегрувати в соціальні підприємства, а бізнес-ідеї у процесі комерціалізації в малі підприсмства. При цьому представники малого та середнього бізнесу зможуть на Майданчику відібрати та 
підготувати студентів і залучити їх до праці на власних виробництвах.

Серед переваг функціонування моделі Майданчику варто виділити такі: засвоєння студентами базових компетенцій ведення бізнесу через практикуми, які проводять підприємці; в умовах реалізації проекту виникає потреба у спеціалізованих знаннях, виходячи з цього студент знає, які дисципліни йому потрібно вивчити, щоб працювати в цьому бізнесі, а викладачам - які зміни потрібно внести до навчального процесу, щоб задовольнити потребу студентів у знаннях; студент, за підтримки викладачів та бізнес-тренерів, набуває практичних навиків щодо створення власної команди для реалізації проекту і вміння працювати в команді.

Висновки і перспективи подалыших досліджень. Студентський майданчик формалізації соціальних ідей та комерціалізації бізнес-ідей у процесі свого розвитку покликаний стати осередком молодіжного та університетського підприємництва в соціальній та бізнесовій сферах регіону.

Усі учасники Майданчика зможуть отримати певні вигоди від його функціонування. Студенти зможуть формалізувати власні ідеї, сформувати команду для іiї реалізації, отримати вузькоспеціалізовані знання в навчальних закладах та практичні навички на діючих підприємствах, працевлаштуватись на існуючих підприємствах. Університети зможуть отримати бази практик для студентів та залучити практиків до підготовки фахівців, що дасть змогу готувати висококваліфікованих спеціалістів, які володіють необхідним рівнем знань та практичних навичок і спроможні їх реалізувати у підприємницькій діяльності. Підприємці зможуть брати участь у підготовці висококваліфікованих кадрів 3 подальшим їх працевлаштуванням на власних підприємства. Місцева влада отримає можливість скоротити молодіжне безробіття в регіоні через створення нових робочих місць та стимулювати соціальне підприємництво через відбір та фінансування проектів Майданчика.

Ефективність функціонування Майданчика залежатиме від міри успішності формування комунікаційних та ділових зв'язків між студентом, викладачем, підприємцем, освітнім закладом і місцевою владою. Тому подальші дослідження потрібно спрямувати на форму- вання інфраструктури Майданчика, на механізми формування та взаємодії центрів, офісів та лабораторій 3 належним технічним, технологічним і інформаційним забезпеченням відповідно до галузевого спрямування та потенційних можливостей регіону, а також на переорієнтацію університетських навчальних програм на потреби бізнесу.

\section{Перелік використаних джерел}

Chukhray, N. I. (2011). Akademichne pidpryyemnytstvo za kordonom ta v Ukrayini. [Academic entrepreneurship abroad and in Ukraine]. Visnyk Natsionalnoho universytetu "Lvivska politekhnika". Menedzhment ta pidpryyemnytstvo $v$ Ukrayini: etapy stanovlennya $i$ problemy rozvytku, 714, 448-458. [In Ukrainian].

Deyneko, L. V., \& Mazaraki, A. A. (Ed.). (2017). Vzayemodiya nauky ta osvity v realizatsiyi innovatsiyno oriyentovanoyi modeli industrializatsiyi. [The Interaction of Science and Education in the Realization of the Innovative Model of Industrialization]. Problemy ta perspektyvy rozvytku innovatsiynoyi diyalnosti v Ukrayini: $K H$ Mizhnarodnyy biznes-forum, (pp. 55-57), 21 bereznya 2017 r. Kyiv: Kyiv. nats. torh.-ekon. un-t. [In Ukrainian].

Dumanska, I. Yu. (2013). Molodizhne innovatsiyne pidpryyemnytstvo yak natsionalna doktryna modernizatsiyi ekonomiky. [Youth Innovation Entrepreneurship as a National Doctrine for the Modernization of the Economy]. Visnyk Khmelnytskoho natsionalnoho universytetu. Ekonomichni nauky, 4(2), 194-200. [In Ukrainian].

Kalenyuk, I., \& Dyachenko, A. (2016). Pidpryyemnytski universytety $\mathrm{v}$ hlobalnomu osvitnomu prostori. [Business Universities in the Global Educational Space]. Mizhnarodna ekonomichna polityka, 2, 59-75. Retrieved from: http://nbuv.gov.ua/UJRN/Mep_2016_2_6. [In Ukrainian].

Pavlenko, A. F., Antonyuk, L. L. (Eds.), Vasylkova, N. V., Ilnytskyy, D. O. et al. (2014). Doslidnytski universytety: svitovyy dosvid ta perspektyvy rozvytku v Ukrayini. [Research Universities: Global Experience and Development Prospects in Ukraine]. Kyiv: KNEU. $350 \mathrm{p}$. [In Ukrainian].

Romanovskyy, O. O. (2012). Fenomen pidpryyemnytstva v universytetakh svitu. [The phenomenon of entrepreneurship at world universities]. Vinnytsya: Nova Knyha. 504 p. [In Ukrainian].

Romanovskyy, O. O. (2015). Rozvytok akademichnoho pidpryyemnytstva i pidpryyemnytskykh vyshchykh navchalnykh zakladiv $v$ umovakh hlobalizatsiyi. [The development of academic entrepreneurship and entrepreneurship in higher education in a globalizing environment]. Retrieved from: http://www.economy.nayka.com.ua/pdf/11_2015/16.pdf. [In Ukrainian].

Т. Б. Данилович, А. С. Гавриляк, В. М. Мельник. Национальный университет "Львовская политехника", г. Львов, Украина

\title{
ФОРМИРОВАНИЕ СТУДЕНЧЕСКИХ ПЛОЩАДОК КОММЕРЦИАЛИЗАЦИИ БИЗНЕС-ИДЕЙ И ФОРМАЛИЗАЦИИ СОЦИАЛЬНЫХ ИНИЦИАТИВ
}

\begin{abstract}
Освещены проблемы молодежного предпринимательства, показаны роль и особенности функционирования отечественных и международных структур университетской среды, которые работают в сфере предоставления консультаций в создании собственного бизнеса. Показано, что, несмотря на несомненную эффективность данных структур в подготовке студентов к работе в современных международных и отечественных компаниях и предоставлении глубоких теоретических знаний, невозможно, в рамках таких школ, привитие студентам узкоспециализированных практических навыков для ведения четко определенного бизнеса. Освещены проблемы реализации социальных студенческих инициатив и привлечения международных донорских организаций к их финансированию. Обоснована целесообразность создания студенческих площадок, как составляющей молодежного и университетского предпринимательства, на котором будут созданы условия для: студентов, по реализации собственных социальных и бизнес-идей; предпринимателей, которые хотят развивать бизнес; педагогов, ученых и специалистов, стремящихся "инвестировать" свои знания, навыки и опыт; университетов, с получением заказов на подготовку специалистов с четко определенными компетенциями. Предложена модель поэтапного создания студенческих площадок с построением инфраструктуры на базе вузов, профтехучилищ, колледжей, общественных организаций и технопарков, с системой коммуникационных связей между студентом, преподавателем, предпринимателем, образовательным учреждением и местными властями.
\end{abstract}

Ключевые слова: молодежное предпринимательство; коммуникационные связи; социальное предприятие; университетская середа; компетенции. 
T. B. Danylovych, A. S. Havryliak, V. M. Melnyk Lviv Polytechnic National University, Lviv, Ukraine

\section{FORMING STUDENT PLATFORMS TO COMMERCIALIZE BUSINESS IDEAS AND TO FORMALIZE SOCIAL INITIATIVES}

The authors have shown the role of youth initiatives in the development of society and solving crisis situations in the economy. The theory and practice of youth entrepreneurship in the university environment based on the study of domestic and international publications is researched. We have defined the features of functioning of such domestic and world-famous business schools as Tech StartUp School, Youth \& Business, Business School at Kyiv-Mohyla Academy, Lviv Business School (LvBS), Insead (France), Harvard Business School (USA), London Business School (UK/OAU), Stanford Business School (USA), etc. The necessity of solving the problem of building effective communication and business relations between the student, the teacher, the entrepreneur, the university and local authorities in realization of their own social initiatives and business ideas of students is determined. The problems of formalization of social student initiatives and attraction of international donor organizations to their financing are highlighted. The model of stage-by-stage creation of a student's platform, infrastructure construction on the basis of universities, vocational schools, colleges, public organizations and technoparks and a system of communication between a student, a teacher, an entrepreneur, an educational institution and local authorities is offered. The direction of further research aimed at improving the site infrastructure, on the mechanisms of formation and interaction of centres, offices and laboratories with the proper technical, technological and informational support is determined. The necessity of reorientation of university curriculum for business needs, of preparation specialists with well-defined competencies, in accordance with the branch direction and potential opportunities of the region is established.

Keywords: youth entrepreneurship; communications; social enterprise; university environment; competence. 